\title{
THE TANNA SPEAR-BECKET.
}

By R. Etheridge, Junr., Curator of the Australian Museum, Sydney.

At a recent meeting $I$ exhibited and described the Spear-beckets of New Caledonia and the New Hebrides, and referred to the use of these implements on the Islands of Tanna, Aneiteum, and Efate in the latter group. At the same time I exhibited a drawing of the Tanna becket copied from the Rev. G. Turner's illustration, ${ }^{*}$ and another of the Aneiteum implement taken from one kindly lent to me by the Rev. J. H. Lawrie.

I am now able, through the kindness of Mr. W. R. Harper, to exhibit an admirable example of the Tanna becket, received by

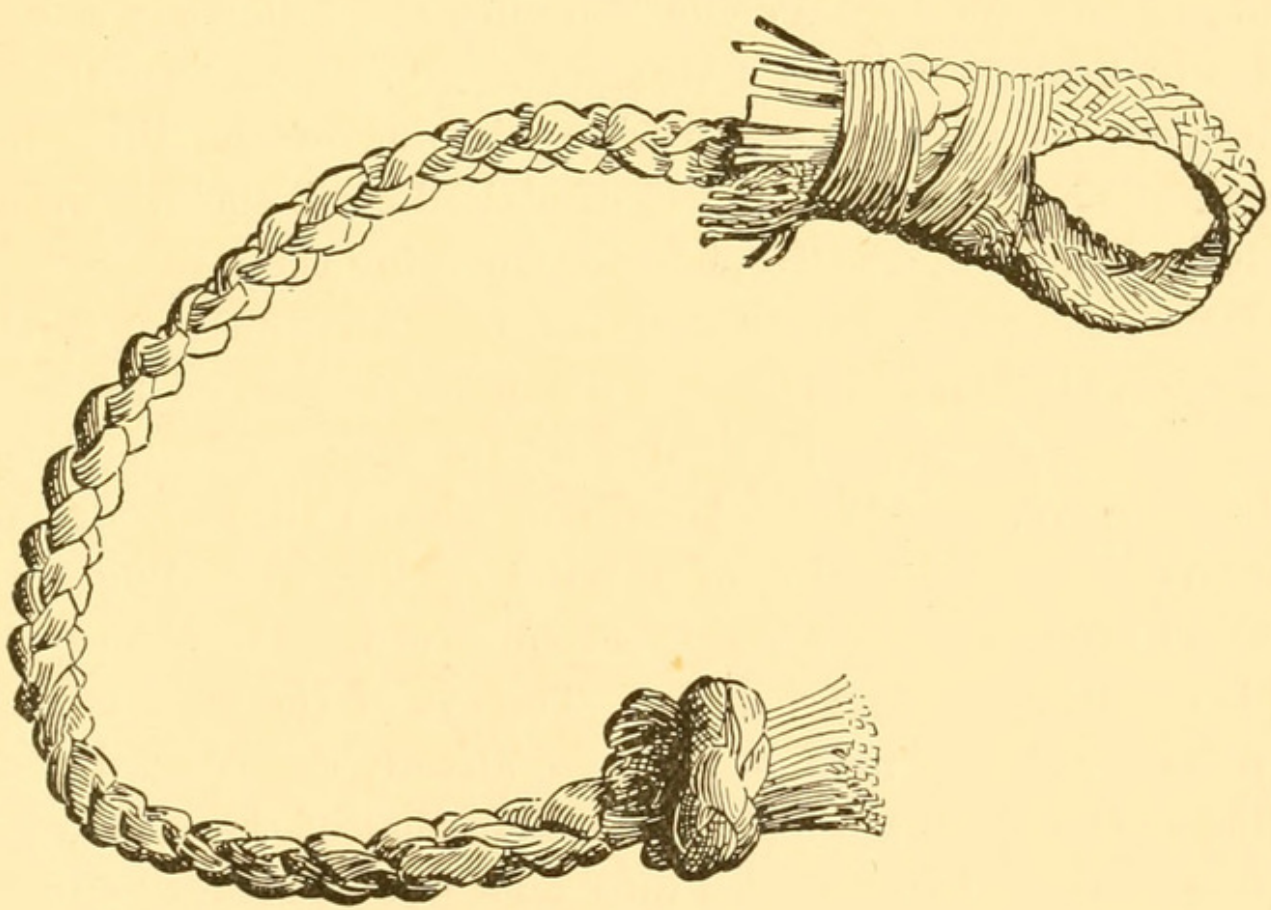

him from the Rev. Dr. Macdonald, of Havannah Harbour, Efate, who, in a letter to Mr. Harper, dated June 26th, 1899, says:"The becket or spear-thrower is, I believe, not known in Efate or to the north. I wrote to Rev. W. Watt, of Port Resolution, Tanna, and he has very kindly brought me a good specimen from

* Nineteen Years in Polynesia, 1861, p. 81. 
Tanna, which I send you. . . . . It appears that the use or knowledge of the becket was confined to the islands south of Efate, that is, Erromanga, Tanna, Aneiteum, Futuna, and Aniwa."

In the first place, this Tanna becket is of much simpler construction than that illustrated by Mr. Turner, in that it has no "tags" or "collar," and the knot is a very simple one. In its simpler construction it resembles the Aneiteum example lent to me by Mr. Lawrie, as well as two of those from the Cook Collection, that I assumed to be New Caledonian, but in the light of the present specimen may be from Tanna or Aneiteum, bearing in mind that Cook called at the former island. In the second place, it will be noted that Dr. Macdonald says the Spear-becket is not known on Efate, but against this I may refer to one of the quotations given in my previous paper. I there stated that in Mr. J. E. Erskine's work, "Journal of a Cruise amongst the Islands of the Western Pacific,"* occurs the following passage relative to Efate:- " From a village . . . a canoe pushed off to intercept us as we were working in, one of the three men occupying it handing up a becket of plaited cord, such as we had seen in the hands of the Tannese for throwing their spears." It seems, therefore, from this discrepancy of statement that further investigation is required as to the use of the becket on Efate.

The Tanna implement forwarded by Dr. Macdonald on bchalf of the Rev. W. Watt is a large one, eleven inches long, and apparently made of strips of a palm spathe, exceedingly well plaited in three strands, forming a round cord. The palm spathe used is possibly that of an Areca. The eye of the cord is made in a precisely similar manner to those already described, but the plaiting of the eye is more elaborate than that of the cord proper. The free ends are not gathered into tags, but left frayed out, and are secured to the standing part of the cord by a thimble of spunyarn wound round, in which the smell of the tar is still faintly, although distinctly perceptible.

I am again indebted to Mr. Hedley's kindness for the drawing accompanying these notes. 


\section{$2 \mathrm{BHL}$ Biodiversity Heritage Library}

Etheridge, Robert and Melo-Costa, Wanessa de. 1899. "The Tanna spear-becket." Proceedings of the Linnean Society of New South Wales 24, 427-428. https://doi.org/10.5962/bhl.part.7675.

View This Item Online: https://www.biodiversitylibrary.org/item/21735

DOI: https://doi.org/10.5962/bhl.part.7675

Permalink: https://www.biodiversitylibrary.org/partpdf/7675

\section{Holding Institution}

MBLWHOI Library

\section{Sponsored by}

MBLWHOI Library

\section{Copyright \& Reuse}

Copyright Status: NOT_IN_COPYRIGHT

This document was created from content at the Biodiversity Heritage Library, the world's largest open access digital library for biodiversity literature and archives. Visit BHL at https://www.biodiversitylibrary.org. 